\title{
JATKUVA KOULUTUS \\ KOULUTUSSUUNNITTELUN PERIAATTEENA
}

- taustoista ja todellisuudesta 1970- ja 80-luvuilla

Jatkuvan koulutuksen periaate on noussut viime vuosina suomalaisen koulutussuunnittelun yhdeksi

perusperiaatteeksi. Siitä puhutaan asiantuntijoiden keskuudessa ja vähemmän asiaa tuntevissa piireissä. Artikkelissa valotetaan kehitystä, joka on johtanut jatkuvan koulutuksen periaatteiden mukaiseen koulutussuunnitteluun. Analyysi kohdistuu elinikäisen kasvatuksen ajatuksen kehitykseen, käsitetulkintoihin ja suunnittelutyöhön. Artikkelissa käsitellään tuoreen tutkimuksen (Pantzar 1991) tuloksia. Tutkimuksen empiirinen osa käsittelee jatkuvan koulutuksen periaatteen asemaa ja tulkintaa 1970- ja 1980-lukujen suomalaisessa koulutussuunnittelussa. Tutkimuksen perusaineiston muodostavat em. ajanjaksolla ilmestyneet koulutusta koskevat komiteanmietinnöt.

\section{Koulutussuunnittelun}

\section{suhteesta}

\section{yhteiskuntapolitiikkaan}

Suomalaisen koulutussuunnittelun tavoitteet kytkeytyvät selkeästi yhteiskuntapolitiikan laajempiin, yleisiin tavoitteisiin. Koulutussuunnittelun yksi tehtävä onkin kehittää julkista koulutustoimintaa yhteiskunnan koko hyvinvointia edistäväksi. Niinpä koulutussuunnittelun päälinjoja saattavat ohjata sellaiset periaatteet, joita ei ensisijaisesti määritellä koulutussektorin sisällä. Toisaalta voi olla myös niin, että koulutussektorin sisäiset suunnitteluideat muotoutuvat laajempien yhteiskunnallisten tavoitteiden mukaan. Erilaiset tasa-arvotavoitteet ovat hyvä esimerkki laajoista yhteiskunnallista pyrkimyksistä, joita on jouduttu tulkitsemaan myös koulutuksen suunnittelussa.
Suomalaisessa koulutussuunnittelussa oli erityisesti 1970-luku komitealaitoksen aikaa. Suunnittelussa komitealaitoksen laajentumisen uskottiin lisäävän demokratiaa muun muassa eri intressiryhmien päästessä mukaan suunnittelutyöhön (Lehtisalo - Raivola 1986, 189-190). Viime vuosikymmenellä tapahtunut yleinen komitealaitoksen aseman heikkeneminen siirsi painopistettä koulutussuunnittelussa opetusministeriön suuntaan.

1970-luvun yhteiskuntasuunnittelun yleinen komiteakeskeisyys kasasi komiteoiden ratkaistavaksi laajoja kysymyksiä. Koulutussuunnittelun kytkeytyminen laajempiin yhteiskunnallisiin kysymyksiin näkyi myös komiteiden laaja-alaisina, normatiivisina toimeksiantoina. Hyvänä esimerkkinä tällaisesta käy Vuoden 1971 koulutuskomitea, joka sai tehtäväk- 
seen muun muassa määrittää koulutuspolitiikan tavoitteet yleisempien yhteiskuntapolitiikan tavoitteiden pohjalta. Viime vuosina yhteydet yhteiskunnan laajempiin kehittämis- ja kohentamispyrkimyksiin ovat heijastuneet koulutussuunnitteluun asetettuina toiveina, joiden täyttyminen muokkaisi koulutusjärjestelmää "hallitun rakennemuutoksen" välineeksi, kansainvälisen kilpailukyvyn kohottajaksi tai taloudellisesta lamasta pelastajaksi.

\section{Jatkuva koulutus ja koulutusjärjestelmäkokonaisuus}

Koulutusjärjestelmän ymmärtäminen kokonaisuutena ja jatkuvan koulutuksen periaate ovat olleet eri tavoin mukana koulutussuunnittelussa niin 1970- kuin 1980-luvulla. Jatkuvan koulutuksen periaatteesta (esiintyy myös termeillä elinikäinen/jatkuva kasvatus) on suunnitteluasiakirjoissa puhuttu jo pitkään. Tapio Vaherva on maininnut periaatetta tarjotun ensimmäisen kerran eri koulutusmuotoja ja -tasoja integroivaksi periaatteeksi jo vuonna 1971, Aikuiskoulutuskomitean I osamietinnössä (Vaherva 1989, 273).

Aikuiskoulutuskomitea näkikin elinikäisen kasvatuksen merkityksen varsin selkeästi. Merkille pantavaa on se, että toimeksiannon aikuiskoulutukseen rajaamisesta huolimatta, komitea kykeni tekemään varsin selkeitä jatkuvan koulutuksen periaatteen mukaisia, koko koulutusjärjestelmää sivuavia ehdotuksia. 1980-luvun lopulla ja 1990-luvun alussa jatkuvan koulutuksen periaatteen määrittäminen koko koulutusta koskevan suunnittelun johtoajatukseksi on ollut itsestäänselvyys.

\section{Elinikäistå kasvatusta ja jatkuvaa koulutusta \\ — käsitteiden ja termien viidakossa}

Oppimisen elinikäisyyttä ja koulutuksen jatkuvuutta kuvaava käsitteistö ja termistö on kolmen viime vuosikymmenen aikana ollut jatkuvassa käymistilassa. Vieläkään selkeää vakiintumista ei ole havaittavissa. Erityisen ongelman muodostaa se, että käsitteitä vastaavat todellisuuden ilmiöt voivat liittyä kovin monella tavalla kasvatukseen ja koulutukseen: oppimisen elinikäisyyteen, jatkuvaan itsensä kehittämisen tarpeeseen, formaalin koulutuksen kestoon ja sen organisointistrategioihin sekä koulutuspolitiikkaan.

Kansainvälistä keskustelua on haitannut kokonaisvaltaisten, käsitejärjestelmää koskevien teoreettisten analyysien vähäisyys. Laajoja teoreettisia käsiteselvityksiä toki löytyy. Suo- messa tutuin tällaisia aineksia sisältävä katsaus on Alasen laatima vertaileva analyysi, jonka perusteellinen UNESCOn (lifelong education), Euroopan Neuvoston (permanent education)ja OECD:n (recurrent education) mallien vertailu tuottaa rakennusaineksia varsinaisen teoreettisen käsitejärjestelmän luomiselle (Alanen 1981). Myös Kjell Rubensonin käsitevertailu (1987) antaa aineksia pätevän käsiteanalyysin tekemiselle. Näiden vertailujen ja muutamien muiden käsitteenmäärittelyjen (esimerkiksi Cropley 1979; Gestrelius 1979; ks. myös Pantzar 1991, 17-) perusteella voidaan käsite- ja termikehityksestä todeta yhteenvetona seuraavaa:

- Ilmiötä kuvaava yleistermi on muuttunut "elinikäisestä kasvatuksesta" "jatkuvaksi koulutukseksi". Jatkuvan koulutuksen käsitesisältö on kuitenkin elinikäistä kasvatusta sup. peampi. Jatkuva koulutus kattaa lähinnä formaalin koulutuksen alueen, elinikäisen kasvatuksen koskiessa kaikkia kasvatuksen muotoja.

- Elinikäisestä kasvatuksesta jatkuvaan koulutukseen siirtyminen on ollut myös siirtymistä kasvatuksen tavoitteiden ja sisältöjen määrittämisestä koulutuspolitiikan ja -suunnittelun pääperiaatteeksi.

- Jaksoittaiskoulutus - alunperin ruotsa. lainen ja OECD:n käyttöönottama malli (ruots. återkommande utbildning; engl. recurrent education), jota pidetään yleisemmin jatkuvan koulutuksen toteuttamisstrategiana kuin sille rinnakkaisena periaatteena (Abrahamsson et al.1988, 100;) , on viime vuosina selvästi vaikuttanut jatkuvaksi koulutukseksi nimettyyn koulutusajatteluun.

\section{Koulutussuunnittelu ja jatkuvan koulutuksen tutkimus}

Koulutussuunnitteluun kohdistuvan tutkimuksen merkitystä on eri yhteyksissä korostettu painottamalla erityisesti koulutussuunnittelun yhteiskunnallista merkitystä ja laajoja yhteyksiä (Antikainen 1987, 268). Tutkimuksen kohdentaminen koulutussuunnitteluun merkitsee myös kasvatustieteellisen tutkimuksen suuntautumista ympäröivään todellisuuteen. Koulutussuunnittelua koskevan tutkimuksen vähäisyys näkyy myös jatkuvan koulutuksen tutkimuksessa. Vahervan ja Rengon raportti "Jatkuva koulutus tutkimuskohteena" (1989) paljastaa laaja-alaisten tutkimusten vähäisyyden. Raportissa tehty ehdotus suomalaiseksi jatkuvan koulutuksen tutkimusohjelmaksi kattaa myös edellä kaivatun suunnitteluun koh. distuvan teema-alueen. 
Muualla jatkuvaa koulutusta koulutussuunnittelun periaatteena on sivuttu esim. muutamissa ruotsalaisissa raporteissa, joissa kuitenkin on pitäydytty jaksoittaiskoulutuksen strategiassa. Se rajoittaa oleellisesti jatkuvan koulutuksen näkökulmia (Abrahamsson 1988; Rubenson 1987).

Toisensuuntaisena esimerkkinä merkittävästä kansainvälisestä katsauksesta elinikäisen kasvatuksen perusteisiin voi mainita DAVEn teoksen "Foundations of Lifelong Education" (Dave 1976), jossa kuitenkin koulutussuunnittelun näkökulma jää taka-alalle. Se on tyypillistä tutkimuksille ja analyyseille, joissa viitekehyksenä on UNESCOn elinikäisen kasvatuksen "Lifelong education" -tulkinta. Koulutussuunnittelun laajan näkökulman huomioonottamista jatkuvan koulutuksen tutkimuksessa on selvästi häirinnyt periaatteen (elinikäinen kasvatus/jatkuva koulutus) monitulkintaisuus.

\section{Jatkuvan koulutuksen periaate koulutussuunnittelun todellisuutena}

Seuraavassa esitettävät havainnot jatkuvan koulutuksen periaatteen käytöstä ja tulkinnasta koulutussuunnittelussa perustuvat tutkimukseeni (Pantzar 1991), jonka empiirisen osan aineiston koostui 1970-ja 1980-luvulla ilmestyneistä koulutusta koskevista komiteanmietinnöistä ( $n=27)$. Tutkimusmetodina käy. tettiin sisällön analyysiä. Kahden vuosikym. menen koulutussuunnittelua suhteessa jatkuvaan koulutukseen arvioitaessa otettiin huomioon myös komiteanmietintöjen asema ja sen muuttuminen koko suunnitteluorganisaatiossa. Tutkimustuloksia onkin tarkasteltu muun koulutussuunnittelun rinnalla, pyrkien vertailemaan komiteoiden ja muiden suunnitteluorganisaatioiden tuotoksia toisiinsa (Pantzar 1991, 69.).

Komiteiden kirjattujen esitysten, komiteanmietintöjen, painoarvoa käytännön koulutustoiminnan kehittämisessä on arvioitava myös osana koko julkisen suunnittelun merkitystä. Se, että komiteain ehdotuksilla ei ole välittömiä oikeusvaikutuksia, siirtää vallan päätöksentekijälle. Monet tutkijat ovat suhtautuneet varsin kriittisesti suunnittelijain uskoon oman työnsä välittömästä merkityksestä (esimerkiksi Vartola 1985, 91). Komiteanmietinnöt onkin nähtävä viesteinä niille, joilla on valta päättää mitä ehdotuksista ruvetaan toteuttamaan. Päätöksentekijän harkintaan vaikuttavat monet ajankohtaiset asiat, jotka saattavat olla ratkaisevasti toisia kuin suunnitteluprosessin ai- kana esiin nousseet. Esimerkiksi taloudellisen tilanteen muutokset ja näkymät ovat usein aikaansaaneet sen, että suunnitteluvaiheen oleellisimpia esityksiä on jouduttu muuttamaan uudistuksia lopulta toteutettaessa.

Komiteoiden suhde jatkuvaan koulutukseen on ollut erilainen riippuen muun muassa komitean suunnittelukohteesta koulutusjärjestelmässä. Puolet tutkimuksen mietinnöistä mainitsee jatkuvan koulutuksen (tai elinikäisen kasvatuksen) periaatteen komitean työskentelyn yhdeksi tärkeäksi näkökulmaksi. Erityisesti aikuiskoulutukseen kohdistuvassa suunnittelussa se näkyi jo 1970-luvulla. 1980-luvulla, siirryttäessä yhä enemmän koulutusjärjestelmän kokonaissuunnitteluun, jatkuvan koulutuksen periaate mainittiin myös muissa mietinnöissä yhä useammin. Mietinnöt eroavat selvästi toisistaan myös niissä esitetty. jen, jatkuvaa koulutusta edustavien näkemysten ja toimenpide-ehdotusten määrässä ja laaja-alaisuudessa. Toimenpide-ehdotusten perusteella näyttää siltä, että periaatteeseen kuuluva kasvatustoimintojen integrointi on ymmärretty muodollisen järjestelmän sisäisenä toimenpiteenä, ts. informaaliin kasvatusjärjestelmään yhdentämistä koskevat selkeät ehdotukset puuttuvat. Toinen usein esitetty ratkaisumalli on pyrkimys jatkuvan koulutuksen nimissä erilaisten kiinteiden järjestelyjen soveltamiseen kaikilla koulutusjärjestelmän osa-alueilla. Se merkitsisi muun muassa tutkintojen lisääntymistä aikuiskoulutuksessa ja opiskelijan valintamahdollisuuksien rajoittumista itselle sopivimpien etsimiseen olemassa olevista "opintopaketeista". Mietintöjen analyysi osittaa selvästi myös sen, että komiteoiden koulutuksen uudistamista koskevat ehdotukset eivät tarkastele koulutusta yhtenäisistä vertikaaleista tai horisontaalisista osakokonaisuuksista (esimerkiksi ammatillinen koulutus) koostuvana järjestelmänä.

\section{Jatkuva koulutus suomalaisen koulutus- suunnittelun kokonaiskuvassa}

Jatkuvan koulutuksen periaate ei ole kyennyt tasoittamaan määrällisen koulutussuunnittelun ylivoimaa. Näyttää jopa siltä, että vuosien vieriessä jatkuvan koulutuksen nimissä tehty suunnittelu on yhä vähemmän kohdistunut koulutuksen laadulliseen kehittämiseen. Uutta on vain suunnittelukohteen muuttuminen koulujärjestelmän osa-alueista koulutusjärjestemäkokonaisuuteen. Elinikäisen kasvatuksen laajan periaatteen pelkistyminen jatkuvan koulutuksen koulutuspoliittiseksi suunnit- 
teluperiaatteeksi on vienyt suunnittelua reflektiivisestä suunnittelusta operatiiviiseen suunnitteluun, ts. keskeiselle sijalle uudistuksissa ovat nousseet mm. koulutusrakenteita koskevat kysymykset.

Jatkuvan koulutuksen nimissä tehtyä suunnittelua on viime vuosina leimannut pyrkimys sellaisiin ratkaisuihin, joiden voi väittää vahvis. tavan koulutuksen kredentialistista luonnetta. Käytännössä kysymys on tavoitteesta kehittää kaikilla tasoilla tutkintoja tuottava ja todistuk. sia antava järjestelmä. Suoritusten vahvistaminen todistuksella ei ole sinänsä väärin. Ongelmaksi saattaa muodostua se, että yhteiskunnan tukitoimet vähitellen kohdistuvat vain tutkintoja tuottavaan koulutukseen. Myös ihmisten käsitykset siitä, mikä on opiskelun arvois. ta, saattavat muuttua ympäristön käsitysten mukaan. Kredentialismi ei ole koulutussuunnittelun tai -järjestelmän tuote. Koulutuksen sektorilla siinä on enemmänkin kysymys ym. päröivän yhteiskunnan antamista toimintamal. leista.

Jatkuvan koulutuksen periaatteen mukaisen koulutussuunnittelun opetussuunnitelmia koskevat ratkaisumallit ovat luonteeltaan samansuuntaisia koulutusrakenteen ja -organisaatioiden uudistamista koskevien ehdotusten kanssa. Epäilemättä kehitys opetussuunnitel. mien uudistamisessa on kulkenut, elinikäisen kasvatuksen aatteen muuttuessa jatkuvaksi koulutukseksi (jaksoittaiskoulutuksesta puhumattakaan), sisällöllisen uudistamisen sijasta ulkoisen remontointiin. Näyttää myös siltä, että jatkuvan koulutuksen mukaisessa koulutussuunnittelussa on palattu opetussuunnitelma. käsitykseen (tai laajemmin sivistyskäsitykseen), jonka olennaisia sisältöjä ovat mahdollisuuksien samanlaisuuden tasa-arvokäsitys, markkinakeskeinen yhteiskuntamalli ja koulu. tuksen työvoimantuottamisfunktion painottaminen. Opetussuunnitelman sanotaan perus. tuvan tällöin tieteellisrationalististiseen sivistys. käsitykseen (Englund 1990, 427-432).

Jatkuvan koulutuksen periaatetta ja näky. miä tarkastellessa on aiheellista palata "lifelong integrated education" -käsitteeseen, jota termiä UNESCO alunperin käytti. "Integrated" on tarkoittanut muodollisen kasvatuksen sisäistä yhdentämistä ja sen niveltämistä kasva. tuksen informaaleihin muotoihin. Toisaalta, usein on viitattu myös tarpeeseen mukauttaa (to integrate) kasvatusta ja koulutusta aikuisen elämänkulkuun ja -tilanteisiin. Jatkuvan koulutuksen suunnittelun mukainen järjestelmä ei kuitenkaan näyttäisi toimivan näin. Vaikuttaa pikemminkin siltä, että myös elämää (elämän- tapaa ja yksittäisiä toimintoja) joudutaan mukauttamaan muodolliseen (jatkuvaan) koulutukseen. Myös edellä käsitelty tutkimus osoit. taa, että suunnittelusta esiin nousevat kehittämisen linjat ja ajatukset - koulutuksen rakenteiden ja organisaatioiden uudistamisen painottaminen, kiinteiden vaihtoehtojen tarjoaminen vs. yksilön itsenäiset valinnat ja tutkintojärjestelmän ulottaminen koko jatkuvaan koulutukseen - asettavat integroitumisvaatimuk. sia elämällemme siinä missä koulutuksellekin. Mitenkään tavoiteltavana ei tarvinne kuitenkaan pitää sellaista jatkuvan koulutuksen yhteiskuntaa, joka asettaa yksilölle kohtuuttomia koulutukseen mukautumisen vaatimuksia.

\section{LÄHTEET}

Abrahamsson, K. (ed.) 1988. Implementing Recurrent Education in Sweden: On Reform Strategies of Swedish Adult Education and Higher Education. Swedish National Board of Education.

Abrahamsson, K. et al. 1988. Recurrent Education in Sweden - Absolute Policy Concept or Guideline for the Future. In: Abrahamsson, K. (ed.) 1988. Pp. 100-117.

Alanen, A. 1981. Elinikäinen kasvatus - jatkuva kasvatus - jaksoittaiskoulutus. Teoksessa: Alanen, A. \& Sihvonen, J. (toim.). Elinikäinen kasvatus. Gaudeamus. Porvoo.

Antikainen, A. 1987. Kasvatustiede, kasvatussosiologia ja koulutuksen kehittäminen. Kasvatus 4, 265-269.

Dave, R.H. (ed.) 1976. Foundations of Lifelong Education. Pergamon Press. Exeter.

Englund, T. 1990. Drei Curriculumkonzepte als Kategorien historisch-vergleichender Analyse. Bildung und Erziehung 4, 427-448.

Lehtisalo, L. - Raivola, R. 1986. Koulutuspolitiikka ja koulutussuunnittelu. WSOY. Helsinki.

Pantzar, E. 1991. Jatkuvaa koulutusta tunnistamassa. Tampereen yliopisto. Aikuis- ja nuorisokasvatuksen laitoksen julkaisuja 28.

Rubenson, K. 1987. Återkommande utbildning. Universitetet i Linköping. Institutionen för pedagogik och psykologi.

Vaherva, T. 1989. Miksi jatkuva koulutus ei kiinnosta? Kasvatus 4, 273-274.

Vaherva, T. - Renko, T. 1989. Jatkuva koulutus tutkimuskohteena. Suomen Akatemian julkaisuja 3. VAPK. Helsinki.

Vartola, J. 1985. Julkisen suunnittelun ajattelutavoista ja luonteesta. VKK. Julkaisusarja B nro 35 . Helsinki. 


\section{AIKUISKASVATUS}

The Finnish Journal of Adult Education

Vol. 11, 3/91

ISSN 0358-6197

Summary

Pantzar Eero 1991. Jatkuva koulutus koulutussuunnittelun periaatteena - taustoista ja todellisuudesta 1970- ja 80-luvuilla.

- Jatkuval elinikäinen koulutus on suomalaisen koulutusajattelun perusperiaatteita. Se on näkynyt kaikessa koulutussuunnittelussa ennen muuta 1970- ja 80-lukujen ajan. Artikkelissa käydään läpi keskeisin koulutussuunnittelun komiteatyöskentely jatkuvan koulutuksen näkökulmasta sekä selvitellään termin rajauksia ja linjauksia sellaisena, kuin se suomalaisessa koulutussuunnittelussa ilmenee.

Aikuiskasvatus 11,3.
Pantzar Eero 1991. Continuing education as the basis of educational planning - backg. round and reality in the 1970 s and 1980s.

- Continuing/lifelong education is part of the fundamental features of Finnish educational thinking. It has been evident throughout educational planning and especially so in the 1970s and 1980s. The article deals with essence of the work of committees involved in educational planning from the point of view of continuing education. The author also presents the limitations of the concept and the policies implemented with regard to it in Finnish educational planning.

Aikuiskasvatus 11,3. 